Témoigner Témoigner. Entre histoire et mémoire

Getuigen Revue pluridisciplinaire de la Fondation Auschwitz

$121 \mid 2015$

Violences radicales en scène

\title{
Turkey - Istanbul as a memory outpost
}

Turquie - Istanbul, poste avancé mémoriel?

\section{Philippe Mesnard}

Translator. Jennie Malcolm

\section{(2)enEdition}

\section{Journals}

Electronic version

URL: https://journals.openedition.org/temoigner/3611

DOI: 10.4000/temoigner.3611

ISSN: 2506-6390

This article is a translation of:

Turquie - Istanbul, poste avancé mémoriel ? - URL : https://journals.openedition.org/temoigner/3606 $[\mathrm{fr}]$

Publisher:

Éditions du Centre d'études et de documentation Mémoire d'Auschwitz, Éditions Kimé

Printed version

Date of publication: 1 October 2015

Number of pages: 156-161

ISSN: 2031-4183

Electronic reference

Philippe Mesnard, "Turkey - Istanbul as a memory outpost", Témoigner. Entre histoire et mémoire [Online], 121 | 2015, Online since 01 October 2016, connection on 04 February 2022. URL: http:// journals.openedition.org/temoigner/3611 ; DOI: https://doi.org/10.4000/temoigner.3611

Tous droits réservés 


\section{Turkey}

\section{ISTANBUL \\ AS A MEMORY OUTPOST}

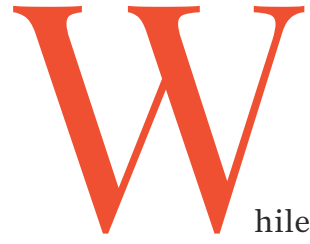

so-called (history and) memory of extreme violence appears to be cut off from the social, "floating" as it were over society and regularly losing sight of it, this is not the case for other geographical areas. Over there, in those other parts of the world, the many uses of memory underscore the dynamic of changing societies - a dynamic that is not generated by politicians or intellectuals, and does not even depend on them. I recently made this observation in Argentina. There I met with members of associations of surprisingly vibrant and open-minded neighborhoods where recollections of the experience of dictatorship, often organized on the same sites where the violence was exercised, combine today social work and political activism. Mutatis mutandis, a similar observation struck me during a recent trip to Istanbul in late June 2015.

The subject of my paper attempts to assert to what extent Turkish society is today a true memorial laboratory. First, memory issues are a determining factor in the socio-political reconfiguration that is currently being realized in Turkey (without overestimating the different shades that will be recovered once this reconfiguration stabilizes). Secondly, the whole process serves as a mirror that allows us to better reflect on the changes underway in Europe, on its identity consisting of multiple national identities (a puzzle that can turn into an alarming colouration of separatism, extremism and radicalism, and the reactions to these).

Then, a caution: in the previous issue of the journal I emphasized the risk of upholding a certain, rather common, line of thought that stigmatizes "Turkey" and the "Turks". This phenomenon can be explained by what Edward Said termed "Orientalism", and is exacerbated by the negative connotation attached to the entire Turkish society because part of it, and its successive governments, refuses to acknowledge that in 1915 there occurred indeed a systematic planning of the annihilation of Armenians living on the national territory, which precisely matches the definition of "genocide". Through the inductive effects that Goffman has clearly analyzed, this stigmatization maywell boost the feeling of national cohesion and thereby strengthen the negationist doxa which is related to the historical identity of this modern state (1963). Rather imagine Istanbul, a decentered city between the Western and Eastern shores of the country, as a memorial bridgehead facilitating the recognition of the Armenian genocide in Turkey, as suggested by Fatih Mehmet Uslu of Şehir University. This is after all a history in which 


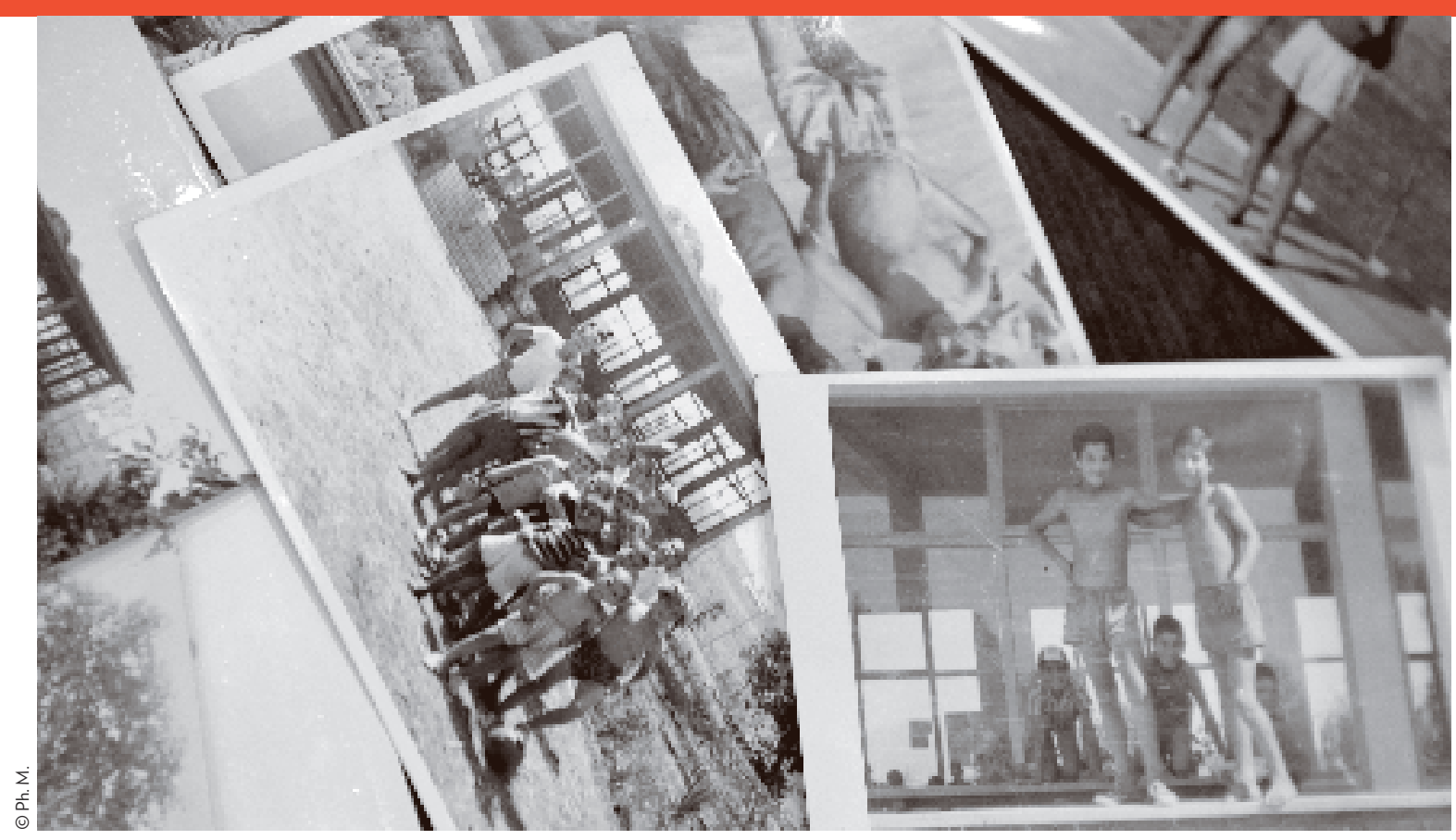

_ Everyday life in Kamp Armen. (1960)

minorities were all, at one time or another, victims of segregation, repression, and expulsion usually accompanied by massacres.

$$
\text { 次次 }
$$

Despite the weakness of its current community, mainly based in Istanbul (it only includes some 60,000 members, which ranks it among the hyper minorities of this world), the memory of the genocide is present on multiple levels. Moreover, those who claim it and advocate for its recognition are extremely involved in the very life of this society. This struck me partly because the memory of the genocide is in fact based on sustained interaction between Turkish and Armenian actors, leading Michel Marian to talk of "shared memory".

Anadolu Kultur, the Hrant Dink foundation, DurDe (SOS Racism) Helsinski Citizens Assembly, IHD (Associations of human rights) are among the associations, foundations and NGOs engaged in this hard work against the current of a dominant culture, where there is little place for the vulnerable victim who is neither a hero nor a martyr. This impermeability, I would say, is not necessarily linked to the political reasons that lie at the basis of the non-recognition of the genocide. Specifically, one of the aspects in which Turkey can be regarded as a true "construction site" in the memorial field lies in the fact that groups like those mentioned above, or individual initiatives, illustrate the desire to reclaim a part of the past that was taken away from society for, obviously, political reasons, but in which culture also played a decisive role.

In effect, the foundation of the modern State and the Republic in 1922 - establishing a radical break with the Ottoman past - was brought about by the Turkish National Movement, at the head of which were many members of the UPC, the party responsible for the genocide. Not only did that facilitate their integration into the state apparatus, but as founding fathers, they were celebrated as heroes (Akçam 2012). In 1926 the Parliament passed a law granting lands and pensions to the families of former members of the UPC. Remarkably, the law applied to the families of two senior officials executed during genocide trials that took place in 1920, as well as some other criminals who were executed by the Armenians in revenge. Not only did this glorious rehabilitation rewrite history but, by annulling the exemplary value of trials, it also forged a $\bullet \bullet$ 


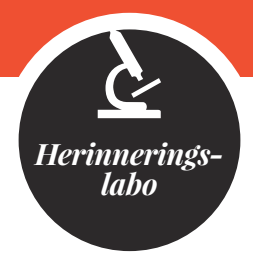

- model of impunity, at least for the powerful and those who served the State's cause. They were allowed to symbolically rise above the law, both in reality and in the national imagination. It seemed as though the relationship between foundation, radical violence and oblivion was now definitively ratified - the oblivion that Renan in 1882 unmistakably qualified, even in the case of historical error, as "an essential factor in creating a nation”(Renan 1997, 13-14; translation JM).

There is another factor that makes modern Turkey's relationship with its past so unique, and the process of acknowledgment even more complex: the masterful alphabetical reform introduced in 1928 on the initiative of Atatürk. By imposing the passage of an ancient writing in Arabic to Latin characters enriched by diacritical signs - a scenario worthy of an Orwell novel - the political power made it difficult for subsequent generations to access official public and private texts of Ottoman history. No one expressed the experience of this estrangement better than Emine Sevgi Özdamar in his eponymous novel Mutterzunge [Mother tongue]:

I will learn Arabic, that was once our script, after our liberation war, 1927, Atatürk forbids the Arabic script and the Latin letters came, my grandfather knew only Arabic script, I knew only Latin alphabet, that is, if my grandfather and I were mute and could only tell each other something through script, we could not tell each other any stories. (Özdamar 1998, 14).

Today, however- that is to say, since a little over a decade-, the rapprochement that takes place in society leads to the emergence of a story which until then had no place, nor was easy to read. Oral histories reveal the existence of a different genealogy through various mediators (Üngör 2015, 57-65; Marchand \& Perrier 2013, 52-66), most of which only spoke out when Hrant Dink, founder of the weekly Agos to which we shall return, gained some visibility in the media field and after his assassination on 19 January 2007 polarized public awareness.

$$
\text { 怾 }
$$

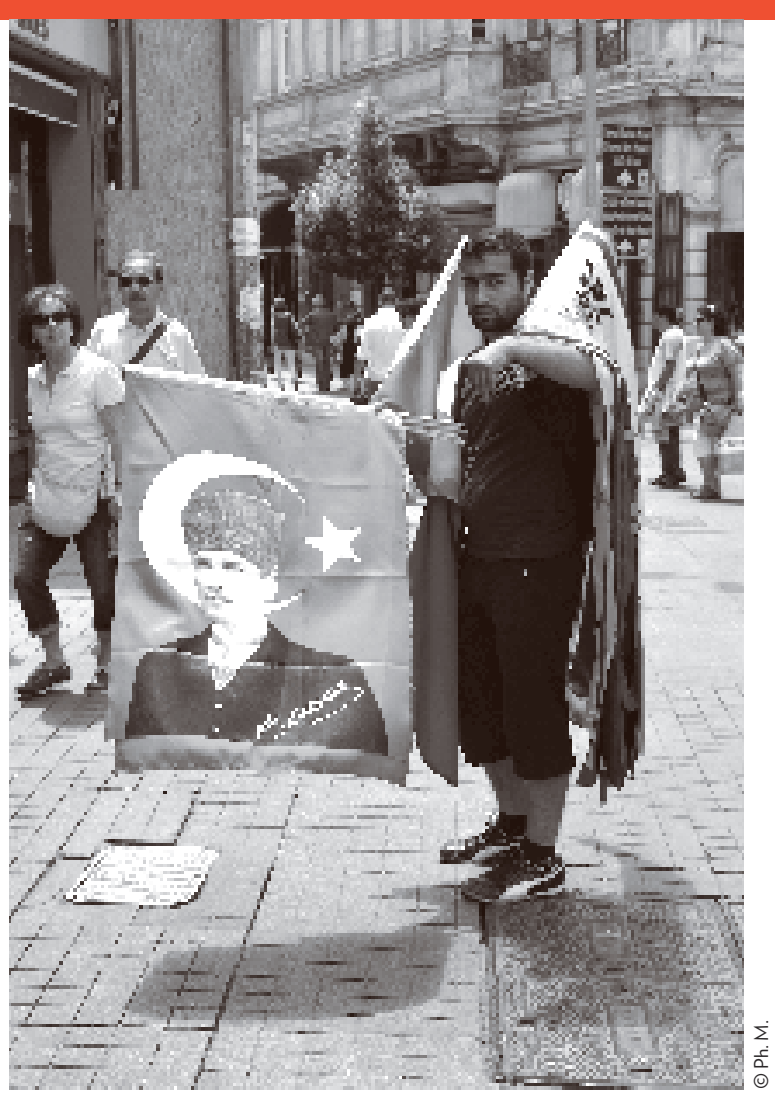

_ In the streets of Istanbul. (2015)

Nor Zartonk means "new renaissance" in the sense of a new beginning and a revival. Its objective is not to preach some kind of Armenian identitarianism, but to make long-silenced Armenian voices in Turkey heard again, while at the same time supporting other minority causes. Sayat, one of the association's leading figures, explains that Nor Zartonk was founded on 18 March 2007, shortly after the death of Hrant Dink. Early in the conversation, he drops the word "activism". Indeed, they are militants who, given their halflibertarian, half-Marxist rhetoric and anti-capitalist leaning (which is evident on their website http://www. norzartonk.org/en) are not always welcomed by the Armenian community, which is generally discreet and normative. While occupying a central position in their activities, demands of genocide recognition and the revival of Armenian culture (the association offers Armenian language courses) appertain to a series of struggles against exclusion, racism, environmental destruction, homophobia and violence against 
women. These are our basic principles, claims Sayat, recognizing also that Nor Zartonk's members could easily be threatened and risk their lives. It feels like a sad mix of romanticism, and the pragmatic realism that is required when you are confronted with ultra-nationalist groups covered by the state. As recently as 2015, several attacks were targeted at specific offices of the HDP, the Democratic Party of pro-Kurdish peoples in Adana and Mersin, others were also perpetrated in Diyarbakir.

On the political level, the recent successes of the HDP party, which Nor Zartonk declares themselves near, during the parliamentary elections of June 2015 are signs of change. This party promotes the normalization of relations between Turkey and Armenia and the recognition of the genocide. It is of course difficult to view the uniqueness of memorial practices in Turkey without considering the place of the Kurds in particular and the minorities in general (Jewish, Greek, Syrian, Chaldean). The Kurds have a singular position of third party in the process of recognition, while in fact they were heavily involved in the 1915 crimes - then they were the middlemen of the killers, their third party. Indeed, we know that they have served as genocide criminals, grouped in gangs or squads (the resemblance to the role of Ukrainian battalions in support of the SS during the Holocaust is tempting). We attribute murders, rapes and other ruthless atrocities to them, as well as looting, abduction of children and women, and forced marriages. This greatly disturbs the question of lineage today in a society whose modern culture did not tolerate foreigners, and where the Kurds had a subaltern position and were long persecuted by a centralist and Jacobean State.

From this perspective, memory issues appear in a different light. Without diminishing their importance, they can be considered a form of resistance against the ultraconservatism of a society that is now slowly beginning to open up. First priority: living together. Under the veil of a social project, destroyed or abandoned sites were located in order to revive or preserve them. But these activities, which combine the claim of recognition and social activism, will long remain a fragile bridgehead of the changes that we see emerging primarily in Istanbul.
The dispute over Kamp Armen serves as an example of the precariousness of the situation. This shelter for young Armenians from Anatolia, former home of Hrant Dink, was opened by Hrant Güzelyan in 1958. Initially, it was to take care of orphans - the "remains of the sword", Kılıç artığı in Turkish, who had escaped the massacres - but later, parents placed their children in this accommodation so they could be raised in an Armenian cultural framework where they learned the language and practiced the religion. A marginal place, therefore, in the heart of Turkey. Beginning with eight residents, this number had increased to eighty boys and girls in 1961, recalls Garabet Orunöz, sixty years old and himself a former habitant of Kamp Armen. In 1962 the community moved to Tuzla, about fifty kilometers from Istanbul. It thrived on self-management, orchards and livestock - an entire era - until January 1983 when it was evacuated, suspected of being a place dedicated to the "Christianization of Muslims" (even though, historically, the opposite actually occurred) and a hide-out for ASALA terrorists. Due to a legal trick prohibiting acquisition of property by the Armenians, the building and grounds, although acquired through a sale, were returned to the previous owner. Güzelyan was arrested and imprisoned for eight months. After his release, he chose exile. Each year, on the last Sunday of April, a pilgrimage takes place to keep this history alive - a history that may too be finally cleared by bulldozers in order to build a residential area on the plot, with the blessing of the local and national government always keen on eradicating traces of Armenian culture in Anatolia.

$$
\text { 棌棌 }
$$

The situation in Kamp Armen is regularly chronicled in Agos, the weekly newspaper founded in 1996 by Hrant Dink and a group of friends. The paper first wanted to report the problems of Armenians living in Turkey and to inform society. Nonetheless, freedom of speech is governed by censorship, and despite Turkey becoming less strict, those who violate the notorious Article 301 of the Penal Code in criticizing Turkey face one year in prison. From the very start, Agos published $\bullet \bullet$ 


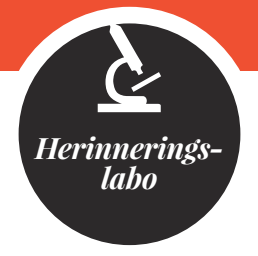

$\bullet$ both in Turkish and Armenian, which was unprecedented since the Republic (and since the genocide). It became the mouthpiece of a silent and restricted community which had bound itself to discretion in fear of provoking reactions from the State and from nationalist circles. But Agos does not dedicate itself to merely being a community spokesperson, thus avoiding the risk of insularity. The journal's print edition now has 5000 regular readers; the electronic edition 10,000.

Its editorial line concentrates on democratization, rights of minorities and on the visibility of the past in which the Armenian genocide occupies a central place. "Agos does not wish to confine itself to denouncing the barbarity of the Turkish crimes", says Yetvart Danzikyan, the journal's current chief editor. No wonder that Nor Zartonk allies itself with Agos, and so do IHD, DurDe, Anadolu Kültur and all those who support a process of democratization in order to, step by step, bend the inflexible state positions. Genocide recognition is in this sense a lever that exceeds the facts themselves and stakes the future of Turkey by and through its coming to terms with its own past and with its communities. It is therefore crucial, insists Danzikyan, not to close in on the past but to strengthen ties with civil society, to raise awareness and bring different communities closer. This openness has however not spontaneously been applauded by the Armenian community, who also felt a kind of fear in revealing her

"secrets", Danzikyan goes on. But isn't it also true that secrets - as painful as they may be - can feed identities from within and thus maintain a kind of cult of misfortune? Paradoxically, it is by working to break this double wall - the denial of the Turkish side and the withdrawal of Turkish Armenians - that Hrant Dink took the risks that led to his assassination.

$$
\text { 怾米 }
$$

The final meeting that I wish to discuss is in fact the first of my short stay. I met Burcin Gerçek in Café Ara near the Galatasaray Lisesi, certainly the most famous high school in Turkey. She is a journalist and, given her profound knowledge of French, she also works as an editor for the Francophone press and on the Armenian-Turkish platform www.repairfuture.net. Burcin Gerçek reveals another side of the history of the genocide. Indeed, this history forces itself upon the Turks today as a part of their country's heritage, not only through the revelations and searches for lost relatives inspired by Fethiye Çetin's The Book of my Grandmother (2004), but also through the recognition that "entirely Turkish" Turks rescued Armenians during the period of the genocide. Some were even killed for this "treason". Who was involved? Were they isolated cases? "They were civil servants, tribal chiefs,

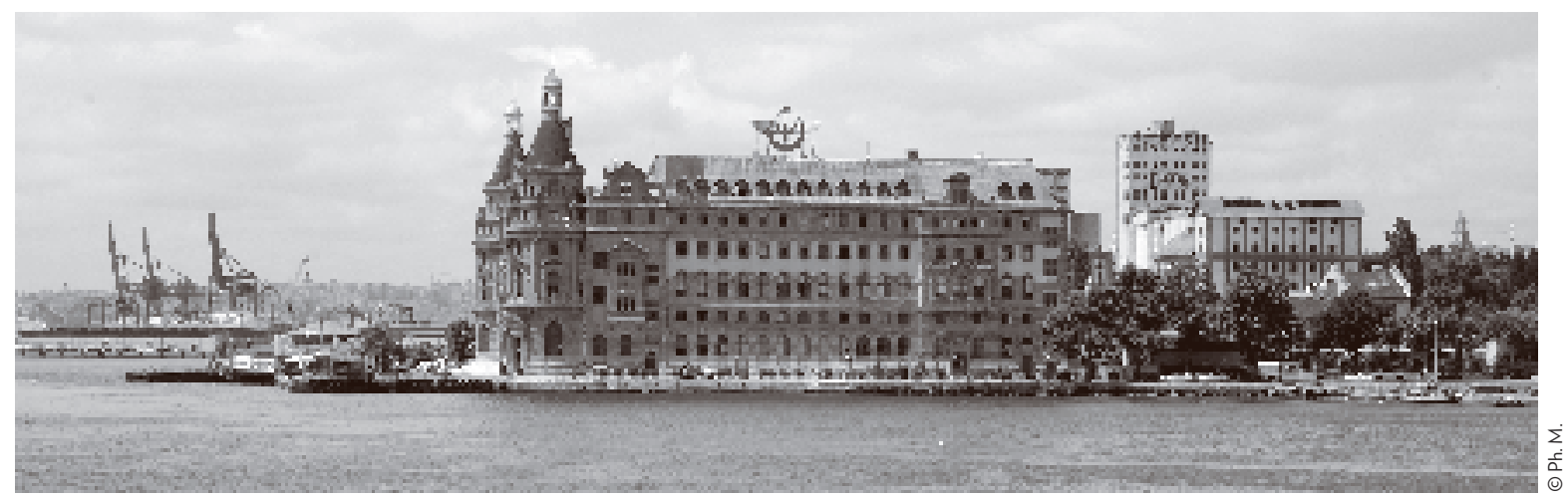

_ The station of Haydarpaşa, in disuse today, was the central station where the trains to the East of the country would depart. Here, convoys left Istanbul in 1915 to deport Armenian citizens. (2015) 
religious persons and other completely 'ordinary' people”, Gerçek asserts, thereby emphasizing that the movement was not trivial, nor local. Her investigation is arduous. The preserved or accessible documents she works with, part of which are written in Arabic characters, need to be confronted, in every single case, to the oral memory of the descendants she collects through interviews. Can we not consider these people as the counterpart of those who, in Europe, are known as the "Righteous" for having saved Jews? "In fact, says Gerçek, there is a terminological problem. We have two terms: vicdanli and hakkaniyetli, which could be translated as 'conscientious', those with a moral conscience." The authorities are very much aware of this important social issue.

From inside Turkey, Burcin Gerçek explains, we cannot just formulate the question in terms of a "recognition of the Armenian genocide". As such, it appears to be merely a problem of politicians. But since society as a whole is concerned, the issue should be addressed in a more appealing way. She insists that the population needs to be put within range of a past that has been, and continues to be, distorted in many ways since the foundation of the Republic. One after the other, the rulers insist on not taking the plunge, they prefer not to stimulate the debate or to support initiatives in this sense. Gerçek further explains: "This is exactly the challenge Adil Hafiza, or 'Just Memory', has taken up. On the principle that 'we all suffered', the project tries to recover those you, in Europe, would term the 'Righteous'." But the government builds its own memory - a counter-memory that exalts nationalism, in particular through commemorations of the centenary of the First World War, for example in Gallipoli where Australian armies and New Zealand suffered a terrible defeat in 1915, the same year that the Armenians were deported and massacred.

The rescuers of Armenians provide a different interpretation on the history of the genocide. "For if Turks indeed took risks to save Armenians, why not recognize the facts today?” suggests Burcin Gerçek, concluding: "We need to offer a new perspective to the Turks, so they can find other ways to relate to this history without having to refer to an official story that still galvanizes national unity despite the anti-Kemalist stance of recent governments. We need to move beyond this monolithic vision, which is at the same time very fragile since it feels threatened by any otherness, especially when this otherness is located within."

(Translation: Jennie Malcolm)

We are very grateful to Sila Cehreli for guiding us through Istanbul as well as through this modest investigation.

\section{WORKS CITED}

- Akçam, Taner, A Shameful Act : The Armenian Genocide and the Question of Turkish Responsibility, London: Metropolitan, 2006.

- Goffman, Erving, Stigma: Notes on the Management of Spoiled Identity, Prentice-Hall, 1963.

- Marchand, Laure \& Guillaume Perrier, La Turquie et le fantôme arménien, forword by Taner Akçam, Arles: Actes Sud, 2013.

- Michel, Marian, Le Génocide arménien. De la mémoire outragée à la mémoire partagée, Paris: Albin Michel, 2015.

- Özdamar, Emine Sevgi, Mutterzunge, Cologne: Kiepenheuer \& Witsch, 1998.

- Üngör, Uğur Ümit, 'On memory, identity, and genocide’, Testimony 120, 2015, 51-69.

- Renan, Ernest, Qu’est-ce qu'une nation?, Paris: Mille et une nuits, 1997.

\section{ERRATUM}

In nummer 120 van Getuigen verscheen binnen de rubriek 'Herinneringslabo' een artikel van Kris Peeters en Myrthel Van Etterbeeck: 'Stefan Hertmans' Oorlog en terpentijn en Jean Echenoz' 14: Over fictie en waarheid, beeld en verbeelding in de hedendaagse roman over de Eerste Wereldoorlog'.

Tot onze grote spijt werd het stuk gepubliceerd zonder de bijbehorende bibliografie:

- Stefan Hertmans, Oorlog en terpentijn [2013], Amsterdam: De Bezige Bij, 2014.

- Jean Echenoz, 14, Parijs: Éditions de Minuit, 2012.

- Pierre Schoentjes, '14 de Jean Echenoz. Un dernier compte à régler avec la Grande Guerre', Critique 786, 2012, 964-981.

- Pierre Schoentjes \& Griet Theeten (red.), La Grande Guerre: un siècle de fictions romanesques, Genève: Droz, 2008.

- Dominique Viart, 'En quête de passé: la Grande Guerre dans la littérature contemporaine', in Pierre Schoentjes \& Griet Theeten (red.), La Grande Guerre: un siècle de fictions romanesques, Genève: Droz, 2008. 